\title{
Transformational Leadership and Innovative Behavior: The Mediating Role of Knowledge Sharing in Indonesian Private University
}

\author{
Suhana Suhana ${ }^{1}$, Udin Udin ${ }^{2}$, Suharnomo Suharnomo $^{3} \&$ Fuad Mas'ud $^{3}$ \\ ${ }^{1} \mathrm{Ph} . \mathrm{D}$. Student of Diponegoro University, Lecturer of Stikubank University, Indonesia \\ ${ }^{2}$ Universitas Muhammadiyah Yogyakarta, Indonesia \\ ${ }^{3}$ Diponegoro University, Indonesia \\ Correspondence: Udin Udin, Universitas Muhammadiyah Yogyakarta, J1 Brawijaya, Geblagan, Yogyakarta, \\ Indonesia. E-mail: udin_labuan@yahoo.com
}

Received: August 24, 2019

Accepted: September 13, $2019 \quad$ Online Published: September 19, 2019

doi:10.5430/ijhe.v8n6p15

URL: https://doi.org/10.5430/ijhe.v8n6p15

\begin{abstract}
Scholars have focused on exploration concerning issues affecting innovative behavior (IB). Of previous research finding reviews, transformational leadership (TL) is seen as the most influential factor to promote IB in the organization. TL helps followers to have a unique opportunity to develop learning competence and cooperation in improving IB. Besides, knowledge sharing (KS) is also supposed as the main trigger to build IB. Therefore, this study aims to analyze the mediating role of $\mathrm{KS}$ in the relationship between TL and IB. 210 postgraduate students in Indonesian private university are determined as samples. Multiple regression analysis by using SPSS software is applied to analyze the data. The results show that TL significantly affects KS and IB. KS further mediates the relationship between TL and IB.
\end{abstract}

Keywords: transformational leadership, knowledge sharing, innovative behavior

\section{Introduction}

In the era of the industrial revolution, land, worker and financial capital are important elements for production. These elements have been shifted by knowledge (Drucker, 1993 in Yu et al., 2013). Knowledge becomes the main source of products and services. To survive in such an environment, organizations should focus on innovation derived from knowledge (Yu et al., 2013). Rawung, Wuryaningrat, and Elvinita (2015) stated that knowledge resource has been essential in improving organization competitiveness.

Innovation is one of the important elements in keeping business sustainability. Innovation constitutes a process in which a member of the organization tries to develop new ideas and implement them to gain better performance (Van de Ven, 1986). Innovation should be an urgent priority for a modern organization to create value in a competitive environment. Innovation by followers is one of the ways to elevate organizational success and competitiveness (Baer, 2012; Pieterse et al., 2010).

The conceptual basis of innovation is a process of problem identification, followed by idea generation, idea support and idea implementation (Kanter, 1988; Scott and Bruce, 1994). The innovation process is influenced by individual motivation, personality, and early knowledge as well as organizational support mechanism (Barron and Harrington, 1981). Individual characteristic triggering innovative behavior is strongly affected by the behavior of the leader. Woodman, Sawyer, and Griffin (1993) proposed an interactive model of organizational innovation. Individual innovation is affected by cognitive capability, character, knowledge, intrinsic motivation and social network. Meanwhile, team innovation is affected by individual innovation, team characteristic, and contextual factors. Organization innovation is influenced by team innovation and contextual factors.

Some scholars have focused on exploration concerning issues affecting follower innovation behavior and how to support the innovation (Yuan and Woodman, 2010). Of previous research finding reviews, leadership is seen as the most important indicator of innovative behavior (Jung et al., 2008). According to Conger (1999), transformational leadership (TL) is seen as one of the most influential factors promoting organizational innovation.

TL theory suppressed innovation triggering as the function of core leadership (Conger, 1999; Tichy and Ulrich, 1984). For Basu and Green (1997), TL constitutes an effective leadership style to elevate innovative behavior. 
Idealized influence as one of the dimensions of TL shows a leader as a trusted, respected and admired figure. The figure stimulates follower potential innovation (Bass, 1999). TL helps followers to get unique opportunity to develop learning and cooperation competence improving innovative behavior, for individual level as well as organizational one (Bass and Riggio, 2006). However, empirical evidence about the role of TL in supporting innovative behavior (IB) is still scarce. Besides, the findings are not consistent (Basu and Green, 1997; Kahai et al., 2003; Shin and Zhou, 2003; Choi et al., 2016). Such a condition indicates that it is important to explore the mediating factor of the relationship.

This article fills the research gap by examining the mediating role of knowledge sharing (KS) in the relationship between TL and IB. KS is predicted to improve organizational and individual innovation. Connelly and Kelloway (2003) argued that KS was supposed to be the main supporter of building innovative behavior. Meanwhile, KS activities are predicted to be affected by the leadership factor. The article also responds Choi et al. (2016) suggestion that more than one industry with the different cultural and national background test the consistency of finding.

KS is a social interaction culture involving knowledge, experience and skill exchange across organizational elements (Hogel et al., 2003). According to Alavi (2000), KS activities improve individual knowledge. The knowledge will be transformed to be organizational knowledge through sharing file, document, and experience among organizational elements. Scholars argued that KS was the prerequisite of innovation (Brown and Eisenhardt, 1995; Verona et al., 2006). In another side, to optimize KS activities, TL is very important. It is in line with literature postulating that TL positively affected to KM, included KS activities (Bryant, 2003; Rawung, Wuryaningrat and Elvinita, 2015).

\section{Literature Review}

\subsection{Innovative Behavior}

Innovation and creativity are often used interchangeably in researches. The difference between the two concepts tended to the difference of suppression instead of the substance (West \& Farr, 1990). Creativity is related with new idea generation that was beneficial (Mumford \& Gustafson, 1988), while innovation is dealt with idea production or adoption and its implementation (Kanter, 1988; Van de Ven, 1986). Researchers have explicitly recognized that idea generation is only one of the stages of the innovation process (Kanter, 1988). Most scholars define innovative behavior from a process perspective. Scott and Bruce (1994) shared innovative behavior to be three stages.

Individual innovation is started with problem identification and idea generation to solve the problem, whether it is a new solution or adoption. During the process stage, an innovative individual seeks to support the idea and tries to build a coalition for support. Finally, in the third stage, an innovative individual produces innovation model. The model then can be institutionalized (Kanter, 1988). From the elaboration, it is concluded that innovation is seen as multistage processes with different activities and behavior of every stage. Tsai and Kao (2004) defined innovative behavior as a whole behavior process initiated with the inspiration of follower innovation, establishment, and implementation of new product and technique or new manufacturing process.

Recently, factors supporting innovative behavior have been intensively studied (Elsbach and Kramer, 2003; Perry-Smith and Shalley, 2003). Mumford (2000) argued that individual innovative behavior was influenced by individual, group and organization. Woodman et al. (1993) stated that individual behavior spread out from an individual to the group and then to the organization. Scott and Bruce (1994) integrated several research streams about innovation antecedent to develop and examine individually innovative behavior. They concluded that leadership style, individual problem-solving and workgroup relation affected innovative behavior directly and indirectly through its effect on innovation climate perception.

\subsection{Transformational Leadership and Knowledge Sharing}

TL is a type of leadership that is suitable to transform the status quo of the organization through personal or collective value system, access to resources and information, effective communication and self-confidence (Bass, 1997). The leaders support followers to have high awareness about the importance of output dan prioritize group interest instead of individual interest. They also pay attention to the follower need, such as proudness and self-actualization. TL is one of the important factors to improve KS activities among followers (Wang and Noe, 2010). Many kinds of research show that there is a direct and positive relation between TL and KS on the individual level (Chen and Barnes, 2006; Garcia-Morales et al., 2008). Meanwhile, Bryant (2003) stated that TL affected KS, whether it is in the individual or group level.

Leadership activities can elevate or decline the atmosphere of the work environment such as KS. Several studies showed that TL created a supportive work climate and gave sufficient resource to accomplish the job efficiently (Lin, 
2006). MacNeil (2004) stressed the importance of TL support in creating organizational KS climate. Barling and Kelloway (1999) stated that TL is a potential predictor of KS to occur.

TL intellectually stimulates followers to be innovative. TL also supports followers to be problem-solvers. TL motivates followers to share the same vision to face the challenge faced by being innovative (Bhatt, 2000; Parent et al., 2000; Mitchel and Nicholas, 2006). They share knowledge, skill, and idea one another to achieve the organizational vision (Johnson, 2002; Fong, 2003; Coff, 2003). A leader bases the instruction and feedback on organizational knowledge. The leader then delivers it to the followers (Szulanski, 1996; Howell and Hall-Merenda, 1999).

TL promotes participative activities and decision-maker practice in organizations (Politis, 2002). The leader facilitates KS between leader and followers. Thus, KS is promoted through organizational management practice of TL. TL style builds the emotional tie of the relationship between a leader and his followers represented by attitude of trust and leader capability (Rawung, Wuryaningrat, and Elvinita, 2015). TL style creates an environment in which followers have a strong tie with their leader. The strong tie between the leader and his follower gives the follower's motivation to share the knowledge that is useful for the organization. Through a strong tie, followers will share their knowledge even though not instructed. It can be concluded that TL can change followers' behavior by building KS activities with their followers. Moreover, TL can affect KM, included KS activities (Bryant, 2003; Rawung, Wuryaningrat and Elvinita, 2015). Thus,

\section{H1: TL significantly affects $K S$}

\subsection{Transformational Leadership and Innovative Behavior}

Basu \& Green (1997) stated that TL is one of the important factors to promote organizational innovation. Innovation constitutes a central issue when discussing TL. Bass (1985) cited by Pieterse et al. (2010) postulated that TL, different from transactional leadership, is more innovative. TL has an important role in transforming and changing process (Bass \& Riggio, 2006). TL supports followers' innovative behavior through inspiration vision statement and opportunities to grow and develop (Basu and Green, 1997).

TL with idealized influence shows optimism with a new perspective. The role improves organizational innovation through intellectual stimulation (Geier, 2016). The level of higher intellectual stimulation will increase exploratory thinking and innovative behavior. Innovative behavior insists followers have strong intension. Such a condition can be fulfilled by TL (Afsar, Badir, and Saeed, 2014). Transformational leader supports followers to try a new perspective in working, change the existing process and system to benefit long term, and help followers to take the effective opportunity. Followers are inspired to show creative effort and increase their analytical capability in problem-solving (Wang, Courtright, and Colbert, 2011; Geier, 2016). Transformational leader help followers to achieve a challenging goal through followers' creativity (Sulistiyani, Udin, \& Rahardja, 2018; Yuan and Woodman, 2010).

TL increases innovative behavior of followers by motivating them to pursue a collective goal (Handayani, Udin, Yuniawan, Wikaningrum, \& Supriyati, 2018; Majumdar and Ray, 2011; Tipu et al., 2012). TL supports the followers' learning and helps them to socialize to get support in implementing the ideas (Geier, 2016). TL influences the idea and implementation of ideas of followers by supporting them to think out of the box through intellectual stimulation (Wang, Courtright and Colbert, 2011). Thus,

\section{H2: TL significantly affects IB}

\subsection{Knowledge Sharing and Innovative Behavior}

Knowledge is very important for the organization to sustain in the turbulent environment. It is in line with Nonaka and Takeuchi (1995) stating that knowledge was the main resource for an organization to guarantee the sustainability organizational operation amid the fast technological change. An organization could gain an outcome when tacit and explicit knowledge interacts spirally under management, sharing and transferring effective knowledge. KS constituted an element stimulating an organization to create knowledge and covers it to be a bigger power (Liebowitz, 2001). When followers are involved in KS intensively, they internalize much knowledge. Such a condition gives benefit to innovative behavior. Holub (2003) stated that faster transfer of knowledge through sharing helped followers to think and create. Socialization, externalization, combination, and internalization have been identified as a conducive environment to create and exchange knowledge (Huang and Wang, 2008; Nonaka and Toyama, 2003). Mom, Van den Bosch and Volberda (2007) showed that knowledge flows of top-down, bottom-up and horizontal affected to the middle manager innovative behavior. 
Radaelli et al. (2014); Wahyudi, Udin, Yuniawan, \& Rahardja (2019) designed three mechanisms connecting follower KS behavior to innovative behavior. Firstly, the direct effect in which sharing action supports recombination and it is the knowledge translation facilitating innovation. Secondly, the indirect effect in which KS creates the social condition, such as reciprocity with new knowledge for innovation purpose. Thirdly, distal effect in which KS antecedents promote innovation.

Moreover, Radaelli et al. (2014) found that followers sharing knowledge will be more engaged in creating, promoting and implementing innovation. KS improves transformation and exploitation capability helping followers to innovation in the accomplishment of their work. It is in line with Choi et al. (2016) that organizational capability to transform and exploit knowledge determined the level of organizational innovation, such as problem-solving and response to the faster environment change. Thus,

\section{H3: KS significantly affects IB}

\subsection{Mediating Role of Knowledge Sharing}

KS is intended to optimize the knowledge repository of follower to act innovatively (Rawung, Wuryaningrat, and Elvinita, 2015). KS is not just a simple process. To optimize the role, the leader's role cannot be neglected. TL is capable of mobilizing followers to share knowledge. The research finding of Noruzyet et al. (2013) indicated that TL positively and indirectly affected to organizational innovation through organizational learning and KM. If a leader plays a transformational one and uses learning organization and KM, organizational innovation can be facilitated and then in turn organizational performance can be elevated.

TL stresses on trust improvement of follower promoting KS among followers and their leader in an organization. Many scholars give argumentation that KS is the prerequisite of innovation (Brown and Eisenhardt, 1995; Verona et al., 2006). KS helps awareness of follower concerning existing problem and challenges being faced. KS insists followers be innovative in the workplace.

Followers working with transformational leadership will be a good knowledge seeker. Followers will share important knowledge with their peers. In turn, KS will improve innovative behavior. Followers having strong intention to develop their skill and expert will help to improve the skill and the expert of their member team. Through expert development, follower shares their knowledge. In other side, followers try to acquire knowledge mastered by their peer. From this side, innovative problem-solving will appear (Choi et al., 2016).

TL improves the intrinsic motivation of followers to share knowledge and skill (Dweck, 1986; Vandewalle, 1997). The higher level of KS will guarantee better organizational work processes, such as: in planning, organizing and coordinating among followers and the improvement of innovative behavior. Thus, TL will elevate the skill of followers and support KS activities, which in turn, support innovative behavior. Thus,

\section{H4: KS mediates the relationship between $T L$ and $I B$}

\section{Research Methods}

\subsection{Respondents}

Postgraduate students of a private university in Indonesia become the object of this study. The researchers distributed 300 questionnaires to the respondents and 210 returned and could be used for analysis. The background of respondents covers 39 teachers, 11 state-owned companies, 95 government officers and 65 private sectors. The data further were analyzed by using SPSS software.

\subsection{Measurement of Constructs}

TL was measured using the 26-item of questionnaires adapted form Bass (1985) which includes 4 dimensions (i.e., vision, charisma, individualized consideration, and morale modeling). KS was measured using the 5-item scale adapted form Bock et al. (2005) which includes 2 items for explicit KS and 3 items for implicit KS. IB was measured using the 14-item scale adapted form Kleysen and Street (2001).

\section{Results}

Based on the validity test conducted to the questionnaire items of TL, KS, and IB, it is known that all items are valid. The significant value is less than 0.05 and correlation value is above 0.5 . Meanwhile, for the reliability test, it is known that Cronbach's Alpha's values of each variables are above 0.7. It is concluded that all questionnaire items are reliable.

Based on the model test ( $\mathrm{F}$ testing) conducted, it is indicated that significant value is $0.000<0.05$. It indicates that the model fits and can be used for the next step. Determination coefficient value for the first model is $23.1 \%$, 
meaning that the variable of independent can explain dependent variable amounted $23.1 \%$. while model $2,47.8 \%$, meaning that variables of independent can explain dependent variable amounted $47.8 \%$. The rest is explained by others not involved in the research.

For hypotheses testing, it is indicated that TL significantly affects KS. It is known from significant value $0.000<0.05$. TL also significantly affects IB. It is known from a significant value of $0.000<0.05$. Meanwhile, KS significantly affects IB. It is seen from significant value $0.000>0.05$. Besides, KS mediates the relationship between TL dan IB. The effect of TL toward IB can be direct or indirect through KS.

\section{Discussion}

Based on data analysis, it is known that TL has a positive and significant effect on KS. The finding strengthens the theory building of the relationship between TL and KS. Several previous types of research concerning the relationship between TL and KS, among others, was conducted by Bass (1985) finding that all dimensions of TL and contingent reward significantly affects all KM dimensions. A leader plays an important role in KS. TL facilitates followers to create the required knowledge (Kreiner, 2002). Moreover, Kerr and Clegg (2007) postulated that leadership was urgent in providing appropriate knowledge, and then in turn affected to KS.

Islam et al. (2011) stated that leadership has a significant effect on KS. Kreiner (2002) also found that a leader could influence followers to create needed knowledge locally. Meanwhile, Kerr and Clegg (2007) stated that the leader helps to create a network of knowledge member and gave the best practice in coordination and collaboration activities. The findings of Crawford (2005) indicated the same result that TL contributed 19,5\% of KM variants. Gowen et al. (2009) found that TL improved whole KS processes in a healthy institution. The finding of Hayat et al. (2015) stated that TL significantly affected KM. TL can play an important role in improving the organizational environment and help to apply the knowledge efficiently. TL has the potential to support followers to be involved in KM processes (Gelard, Zahra and Ali, 2014).

Analoui, Doloriert, and Sambrook, (2013) studied 111 managers of knowledge in Information and Communication Technology (ICT) of UK. They concluded that there is a positive and significant relationship between $\mathrm{Tl}$ adopted by knowledge management and organizational KM activities. Politis (2001) mentioned that TL supported and facilitated KS. TL constitutes the most effective approach in improving KS in the organization (Garcia-Morales et al, 2008). Moreover, Tombul (2011) studying police officer found that TL significantly affected KS of police member.

Leadership had an important role in the knowledge process, such as sharing, creation, and capture (Srivastava et al, 2006) and successful KM implementation (Liebowits, 1999). Noruzy, A. et al., (2013) postulated that leadership was very important in KM efforts.

The second finding is TL significantly affects innovative behavior. Many findings are in line with the current study. Harbone and Johne (2003) mentioned that leadership style was one of the most influential factors to individual innovation. The leader can directly introduce new ideas in the organization and support the innovation initiative to the follower. Specifically, many scholars specify their research on the TL effect on innovation (Howell \& Avolio, 1993. Many characteristics of TL are relevant to organizational innovation. TL has an interactive vision, attention to communication and effective value sharing (Adair, 1990) and supports the conducive environment for team innovation (Tushman \& Nadler, 1986).

TL supports creativity being prerequisite of innovation (Kahai et al, 2003). TL helps followers to see problems from a different perspective and help followers to develop their creativity. Meanwhile, Jong and Hartog (2007) identified that intellectual stimulation can create followers' opportunity to voice new ideas being able to support innovative behavior. According to Elkins and Keller (2003), TL behavior was determinant of innovation and creativity. Inspirational motivation and intellectual stimulation dimensions are two important dimensions in organizational innovation. Moreover, the research's finding of Gumusluoglu and Ilsev (2007) showed that TL significantly influenced organization innovation.

Intrinsic motivation constituting one of the specific characteristics of TL is the main factor of followers' creativity and organizational innovation (Zhou, 2003). Meanwhile, intellectual stimulation of TL can facilitate out of the box thinking and innovation being basic of organization innovation (Dougherty \& Hardy, 1996). The research result of Chow and $\mathrm{Wu}$ (2006) showed that TL significantly influences on organizational innovation. TL promotes innovation and improves knowledge creation compared with transactional one (Crawford and Strohkirch, 2002).

Imran and Anis-ul-Haque (2011) found evidence that TL also affected innovation behavior, directly or indirectly. TL influenced innovative behavior (Borner, Eisenbeiss \& Griesser, 2007; Jung, Chow and Wu, 2003; Lee and Jung, 2006; Reuvers et al, 2008). While Tipu, Ryan, and Fantazy (2012) found that TL affected the followers' propensity 
to innovate. Reuvers et al., (2008) found a positive and strong relationship between TL and innovative work behavior. Jung, Chow, and $\mathrm{Wu}$ (2003) also argued that TL can directly or indirectly affect organizational innovation. TL improved IWB by motivating followers to pursue a collective goal (Majumdar and Ray, 2011) and support individual learning and help followers to implement ideas (Kahai et al, 2003). Thus, TL influences idea promotion of follower and their implementation by supporting them to think out of the box through intellectual stimulation, strengthen social tie among peers, involve followers in every organization activities, pay attention of intrinsic motivation and the need to develop and to recognize. The finding of Afsar and Saeed (2014) was in line with the previous one that TL affected to IWB. TL positively influences idea generation and creativity of followers as well as idea implementation.

Garcia-Morales, Llorens- Montes, and Verdu-Jover (2008) found that TL affected to innovative behavior. Through intellectual stimulation and individualized consideration, TL produces the way to think, seek new opportunity and new problem solution. They give a contribution to improving intrinsic motivation, inspire and support creativity. They play role model articulating shared innovation vision (Senge et al., 1994).

The third findings are that KS significantly influences IB. Several pieces of research indicated that KS improved capability of organizational innovation performance (Calantone, et al., 2002). Meanwhile, Lin (2007) stated that the willingness of followers donated and collected knowledge related to organizational innovation capability significantly. Donate and Pablo (2015) mentioned that effective KM appeared in literature as a method to increase organizational innovation capacity. Moreover, Darroch \& McNaughton (2002) concluded that KM practices were generally dealt with innovation performance.

KS is an important element in supporting an organization to create knowledge and convert them to be strong power (Liebowitz, 2001). When followers are engaged in KS, they internalize the knowledge. Such condition benefits innovative behavior. Holub (2003) stated that the faster transfer of knowledge through KS increases the followers' thinking and creating capability. According to Noruzy et al. (2013), TL positively and indirectly affected to organization behavior through organizational learning and KM. Many kinds of research showed that KM positively influenced organizational innovation. Therefore, organizational learning and $\mathrm{KM}$ play an important role in connecting TL and innovation. Moreover, $\mathrm{Yu}, \mathrm{Yu}$, and $\mathrm{Yu}$ (2013) stated that KS increased follower innovative behavior and innovation capability. The manager should actively strengthen the comprehension concerning KS so followers can share knowledge and in turn, will affect to follower innovative behavior.

The current research findings show that KS has a mediating role in the relationship between TL and IB. The findings are in line with many previous kinds of research. Noruzy et al (2013) indicated that TL positively and indirectly has an important relationship with organizational innovation through organizational learning and KM. KM is one of variable bridging the relationship between TL and organizational innovation. If a leader does not pay attention about $\mathrm{KM}$, the organizational innovation will face barriers.

The findings of Zhu and $\mathrm{Mu}$ (2016) also indicated that KS plays fully as a mediating variable of the relationship between TL and IB. KS helps followers develop new approaches to overcome problems faced in the workplace. Thus, KS improves innovation capability and also their job performance. A leader should create a conducive atmosphere to support KS in the workplace. Meanwhile, the findings of Choi et al. (2016) showed that KS mediates the relationship between TL and IB. TL motivates followers to share knowledge. Thus, KS among followers creates IB. The shared knowledge supports TL and followers to respond to new information and environment fastly, accomplish the job efficiently and finish problems appearing, in turn, improve innovative capability (Chen, 2002).

\section{Conclusion}

This study concludes that TL significantly affects KS and IB. KS further mediates the relationship between TL and IB. From the theoretical perspective, the findings contribute to the theory building of the relationship between TL, KS, and IB. The current results also strengthen the previous findings that KS mediates the relationship between TL and IB. From a practical perspective, to build innovative behavior, management is important to develop TL skill in organizations. TL inspires followers to behave innovatively through the increase of intellectual activity and the growing of cooperation climate. Besides, management is urgent to facilitate KS activities to directly improve innovation behavior.

This study has some limitations. First, this study uses a self-report type questionnaire. Some scholars criticize that a self-report scale has higher biased potential. Second, this study uses individual-level analysis, while TL is theoretically more effective on a team level. To give a clearer description of the theoretical building of team level, 
future research is suggested to use team-level analysis. Future research is also suggested to research the different background of cultures and countries.

\section{References}

Afsar, B., Badir, Y.F. \& Saeed, B.B. (2014). Transformational leadership and innovative work behavior. Industrial management \& Data Systems, 114(8), 1270-1300. https://doi.org/10.1108/IMDS-05-2014-0152

Alavi, M. (2000). Managing organizational knowledge. Framing the Domains of IT Management. Cincinnati: Pinnaflex Educational Resources, Inc.

Analoui B., D., Dololiert, C.H. \& Sambrook, S. (2013). Leadership and knowledge management in UK ICT organizations. Journal of management development, 32(1), 4-17. https://doi.org/10.1108/02621711311286892

Baer, M. (2012). Putting creativity to work: the implementation of creative ideas in organizations. Academy of management journal, 55(5), 1102-1119. https://doi.org/10.5465/amj.2009.0470

Barron, F. \& Harrington, D.M. (1981). Creativity, Intelligence \& personality. Annual review of psychology, 32(1), 439-476. https://doi.org/10.1146/annurev.ps.32.020181.002255

Bass, B.M. (1985). Leadership and performance beyond expectations, Free Press, New York, NY.

Bass, B.M. (1997). Does the transactional-transformational leadership paradigm transcend organizational and national boundaries? American Psychologist, 52(2), 130-139.

Bass, B.M. (1999). Two decades of research and development in transformational leadership. European journal of work and organizational psychology, 8(1), 9-32. https://doi.org/10.1080/135943299398410

Bass, B.M \& Riggio, R.E. (2006). Transformational leadership. Lawrence Erlbaum.

Basu, R. \& Green, S.G. (1997). Leader-member exchange and transformational leadership: an empirical examination of innovative behaviors in leader-member dyads. Journal of Applied Social Psychology, 27, 477-499. https://doi.org/10.1111/j.1559-1816.1997.tb00643.x

Bhatt, G.D. (2000). Information dynamics, learning and knowledge creation in organizations. The learning organization, 7(2), 89-99. https://doi.org/10.1108/09696470010316288

Brown, S.L. \& Eisenhardt, K.M. (1995). Product development: Past research, present findings \& future directions. Academy of management review, 20(2), 343-378. https://doi.org/10.5465/amr.1995.9507312922

Bock, G. W., Zmud, R. W., Kim, Y. G. \& Lee, J. N. (2005). Behavioral intention formation in knowledge sharing: Examining the roles of extrinsic motivators, social-psychological factors \& organizational climate. MIS quarterly, 29(1), 87-111.

Bryant, S.E. (2003). The role of transformational and transactional leadership in creating, sharing and exploiting organizational knowledge. Journal of leadership \& organizational studies, 9(4), 32-44. https://doi.org/10.1177/107179190300900403

Calantone, R.J \& Cavusgil, S.T. \& Zhao, Y. (2002). Learning orientation, firm innovation capability \& firm performance. Industrial marketing management, 31(6), 515-24. https://doi.org/10.1016/S0019-8501(01)00203-6

Chen, L.Y. (2002). An examination of the relationship between leadership behavior and organizational commitment at steel companies. Journal of applied management and entrepreneurship, 7(2), 122-142.

Chen, L.Y. \& Barnes, F.B. (2006). Leadership behaviors and knowledge sharing in professional service firms engaged in strategic alliances. Journal of applied management and entrepreneurship, 11, 51-69.

Choi, S.B. (2016). How transformational leadership facilitates the innovative behavior of Korean workers. Examining mediating and moderating processes. Personnel Review, 45(3), 459-479. https://doi.org/10.1108/PR-03-2014-0058

Chow, C.W \& Wu, A. (2008). Towards understanding the direct and indirect effects of CEOs' transformational leadership on firm innovation. The leadership quarterly, 19, 582-594. https://doi.org/10.1016/j.leaqua.2008.07.007

Coff, R. (2003). The emergent knowledge-based theory of competitive advantage: an evolutionary approach to integrating economics and management. Managerial and decision economics, 24(4), 245-251. https://doi.org/10.1002/mde.1127

Conger, J.A. (1999). Charismatic and transformational leadership in organizations: an insider's perspective on these 
developing streams of research. The leadership quarterly, 10(2), 145-162. https://doi.org/10.1016/S1048-9843(99)00012-0

Connelly C.E. \& Kelloway, E.K. (2003). Predictors of employees' perceptions of knowledge sharing cultures. Leadership and organizational development journal, 24(5), 294-301. https://doi.org/10.1108/01437730310485815

Crawford, C.B. (2005). Effects of transformational leadership and organizational position on knowledge management. Journal of Knowledge Management, 9(6), 6-16. https://doi.org/10.1108/13673270510629927

Crawford, C.B. \& Strohkirch, C.S. (2002). Leadership education and management of knowledge organizations: an overview. Journal of leadership education, 1(2), 18-32.

Darroch, J. \& McNaughton, R. (2002). Examining the link between knowledge management practice and types of innovation. Journal of intellectual capital, 3(3), 210-222. https://doi.org/10.1108/14691930210435570

Donate, M.J. \& Pablo, J.D. (2015). The role of knowledge-oriented leadership in knowledge management practices and innovation. Journal of business research. 68, 360-370. https://doi.org/10.1016/j.jbusres.2014.06.022

Dougherty, D. \& Hardy, C. (1996). Sustained product innovation in large, mature organizations overcoming the innovation-to-organization problem. Academy of management journal, 39, 1120-1153. https://doi.org/10.5465/256994

Dweck, C.S. (1986). Motivational process affecting learning. American Psychologist, 4l(10), 1040-1048. http://dx.doi.org/10.1037/0003-066X.41.10.1040

Elkins, T. \& Keller, R.T. (2003). Leadership in research and development organizations; a literature review and conceptual framework. The leadership Quarterly, 14, 587-606. https://doi.org/10.1016/S1048-9843(03)00053-5

Elsbach, K.D., \& Kramer, R.M (2003). Assessing creativity in Hollywood pitch meetings: evidence for a dual-process model of creativity judgments. Academy of Management Journal, 46, 283-301. https://doi.org/10.5465/30040623

Fong, P.S. (2003). Knowledge creation in multidisciplinary project teams: an empirical study of the process and their dynamic interrelationships. International journal of project management, 21(7), 479-486. https://doi.org/10.1016/S0263-7863(03)00047-4

Garcia-Morales V.J, Llorens-Montes, F.J \& Verdu-Jover, A.J. (2008). The effect of transformational leadership on organizational performance through knowledge and innovation. British journal of management, 19(4), 299-319. https://doi.org/10.1111/j.1467-8551.2007.00547.x

Geier, M.T. (2016). Leadership in extreme context: transformational leadership, performance beyond expectation? Journal of leadership and organizational studies, 2(1), 1-4. https://doi.org/10.1177/1548051815627359

Gelard, P., Zahra, B \& Ali, M. (2014). Relationship between transformational leadership and knowledge management. International Journal of information science and management, 12(2), 67-82.

Gowen, C.R., Henagan, S.C. \& McFadden, K.L. (2011). Knowledge management as a mediator for the efficacy of transformational leadership and quality management initiatives in the US, health care. Health Care Management Review, 34(2), 129-40. doi: 10.1097/HMR.0b013e31819e9169

Gumusluoglu, 1. \& Ilsev, A. (2009). Transformational leadership, creativity \& organizational innovation. Journal of business research, 62, 461-473. https://doi.org/10.1016/j.jbusres.2007.07.032

Handayani, S., Udin, Yuniawan, A., Wikaningrum, T. \& Supriyati, S. (2018). Investigating the link between transformational leadership, psychological empowerment, affective commitment and organizational citizenship behavior in the pharmaceutical sector of Indonesia. International Journal of Pharmaceutical Sciences and Research, 9(2), 766-774. http://dx.doi.org/10.13040/IJPSR.0975-8232.9(2).766-74

Harbone, P. \& Johne, A. (2003). Creating project climate for successful product innovation. European journal of innovation management, 6(2), 118-132. https://doi.org/10.1108/14601060310475273

Hayat, A (2015). The role of transformational leadership and its knowledge management processes. Journal of Health Management \& Informatics, 2(2), 42.

Hogel, M. (2003). Team level antecedents of individuals' knowledge networks. Decision Sciences, 34(4), 741-770. https://doi.org/10.1111/j.1540-5414.2003.02344.x 
Howel, J.M. \& Avolio, B.J. (1993). Transformational leadership, transactional leadership, locus of control \& support for innovation: Key predictors of consolidated-business-unit performance. Journal of Applied Psychology, 78(3), 891-902.

Huang, J.C. \& Wang, S.F. (2008). Team knowledge conversion abilities composition and knowledge sharing, knowledge creation \& innovation performance. an empirical study of a new perspective on knowledge spiral theory. Organization and management, 1, 39-72.

Imran, R. \& Anis-ul Haque, M.A. (2011). Mediating effect of organizational climate between transformational leadership and innovative work behavior. Pakistan Journal of Psychological Research, 26(2), 183-199.

Islam, M.Z. (2011). Organizational culture and knowledge sharing: Empirical evidence from service organizations. African Journal of Business Management, 5(14), 5900-5909.

Johnson, W.H. (2002). Assessing organizational knowledge creation theory in collaborative R \& D projects. International journal of innovation management, 6(4), 387-418. https://doi.org/10.1142/S1363919602000653

Jong, P.J \& Hartog, D.N. (2007). How leaders influence employees' innovative behavior. European journal of innovation, 10(1), 41-64. https://doi.org/10.1108/14601060710720546

Jung, D., Chow, C. \& Wu, A. (2003). The role of transformational leadership in enhancing organizational innovation: Hypotheses and some preliminary findings. The leadership quarterly, 14(4/5), 525-544. https://doi.org/10.1016/S1048-9843(03)00050-X

Jung, D.D, Wu, A. \& Chow, C. (2008). Towards understanding the direct and indirect effects of CEOs' transformational leadership on firm innovation. The leadership quarterly, 19(5), 582-594. https://doi.org/10.1016/j.leaqua.2008.07.007

Kahai, S.S., Sosik, J.J. \& Avolio, B.J. (2003). Effects of leadership style, anonymity \& rewards on creativity-relevant processes and outcomes in an electronic meeting system context. The leadership Quarterly, 14, 499-524. https://doi.org/10.1016/S1048-9843(03)00049-3

Kanter, R.M (1988). When a thousand flowers bloom: structural, collective and social conditions for innovation in organizations. Research in Organizational Behavior, 10, 169-211.

Kerr, M., \& Clegg C. (2007). Sharing the knowledge: contextualizing socio-technical thinking and practice. The Learning Organization, 14(5), 423-435. https://doi.org/10.1108/09696470710762646

Kleysen, R. F. \& Street, C. T. (2001). Toward a multi-dimensional measure of individual innovative behavior. Journal of intellectual Capital, 2(3), 284-296. https://doi.org/10.1108/EUM0000000005660

Kreiner, K. (2002). Tacit knowledge management: the role of artifacts. Journal of Knowledge Management, 6(2), 112-23. https://doi.org/10.1108/13673270210424648

Lee, Y.D. \& Jung, G. (2006). Leadership style and innovation ability: An empirical study of Taiwanese wire and cable companies. The journal of American Academy of Business, 9(2), 218-222.

Liebowitz, J. (2001). Knowledge management and its link to artificial intelligence. Experts systems with applications, 20, 1-6. https://doi.org/10.1016/S0957-4174(00)00044-0

Lin, H.F. (2006). Impact of organizational support on organizational intention to facilitate knowledge sharing. Knowledge management research and practice, 4(1), 26-35. https://doi.org/10.1057/palgrave.kmrp.8500083

Lin, H.F. (2007). Knowledge sharing and firm innovation capability: an empirical study. International journal of manpower, 28(3), 315-332. https://doi.org/10.1108/01437720710755272

MacNeil, C.M. (2004). Exploring the supervisor role as a facilitator of knowledge sharing in teams. Journal of European Industrial Training, 28(1), 93-102. https://doi.org/10.1108/03090590410513901

Mumford, M.D. (2000). Managing creative people: strategies and tactics for innovation. Human resource management review, 10, 313-351. https://doi.org/10.1016/S1053-4822(99)00043-1

Nonaka, I. \& Takeuchi, H. (1995). The knowledge-creating company; how Japanese companies create the dynamics of innovation. New York; Oxford University Press.

Nonaka, I. \& Toyama, R. (2003). The knowledge-creating theory revisited: knowledge creation as a synthesizing process. Knowledge management research and practice, 1, 2-10. https://link.springer.com/chapter/10.1057/9781137552105_4 
Noruzy, A. (2013). Relations between transformational leadership, organizational learning, knowledge management, organizational innovation and organizational performance: an empirical investigation of manufacturing firms. The international journal of advanced manufacturing technology, 64(5), 1073-1085. https://link.springer.com/article/10.1007/s00170-012-4038-y

Parent, M. (2000). Knowledge creation in focus groups: can group technologies help. Information and management, 38(1), 47-58. https://doi.org/10.1016/S0378-7206(00)00053-7

Perry-Smith, J.E. \& Shalley, C.E. (2003). The social side of creativity: A static and dynamic social network perspective. Academy of management journal, 28, 89-106. https://doi.org/10.5465/amr.2003.8925236

Pieterse, A.N. (2010). Transformational and transactional leadership and innovative behavior: the moderating role of psychological empowerment. Journal of organizational behavior, 31(4), 609-623. https://doi.org/10.1002/job.650

Politis, J.D. (2001). The relationship of various leadership styles to knowledge management. Leadership and Organizational Development Journal, 22(8), 354-364. https://doi.org/10.1108/01437730110410071

Politis, J.D. (2002). Transformational and transactional leadership enabling knowledge acquisition of self-managed teams: the consequences of performance. Leadership and organization development journal, 23, 186-197. https://doi.org/10.1108/01437730210429052

Radaelli, G. (2014). Knowledge sharing and innovative work behavior in healthcare: A micro-level investigation of direct and indirect effects. Creativity and innovation management, 23(3), 400-414. https://doi.org/10.1111/caim.12084

Rawung, F.H. (2015). The influence of transformational and transactional leadership on knowledge sharing: am an empirical study on small and medium businesses in Indonesia. ASEAN academy of management journal, 20(1), 123-145.

Reuvers, M. (2008). Transformational leadership and innovative work behavior: exploring the relevance of gender $\begin{array}{lllll}\text { differences. } \quad \text { Creativity } \& \text { Innovation } & \text { Management, } & \text { 17(3), } & \text { 227-244. }\end{array}$ https://doi.org/10.1111/j.1467-8691.2008.00487.x

Scott \& Bruce. (1994). Determinants of innovative behavior; A path model of individual innovation in the workplace. The Academy of Management Journal, 37(3), 580-607. https://doi.org/10.5465/256701

Senge, P.C. (1994). The Fifth Discipline Fieldbook. New York.

Shin, A.J. \& Zhou, J. (2003). Transformational leadership, conservation \& creativity: Evidence from Korea. Academy of Management Journal, 46, 703-714. https://doi.org/10.5465/30040662

Srivastava, A., Bartol, K.M \& Locke, E.A. (2006). Empowering leadership in management teams: effects on knowledge sharing, efficacy \& performance. Academy of management journal, 49(6), 1239-1251. https://doi.org/10.5465/amj.2006.23478718

Sulistiyani, E., Udin \& Rahardja, E. (2018). Examining the effect of transformational leadership, extrinsic reward \& knowledge sharing on the creative performance of Indonesian SMEs. Quality - Access to Success, 19(167), 63-67.

Szulanski, G. (1996). Exploring internal stickiness: Impediments to the transfer of best practice within the firm. Strategic management journal, 17(2), 27-43.

Tichy, N.M \& Ulrich, D.O. (1984). The leadership challenge-a call for the transformational leader. Sloan management review, 26(1), 59-68.

Tipu, S.A.A. (2012). Transformational leadership in Pakistan: an examination of the relationship of transformational leadership to organizational culture and innovation propensity. Journal of management and organization, 18(4), 461-480. https://doi.org/10.1017/S1833367200000705

Tombul, F. (2011). The impact of leadership styles and knowledge sharing on police officer's willingness to exert extra effort to provide better security: a study in the riot unit of the Turkish National Turkish National Police. University of North Texas, USA.

Tsai, C.T. \& Kao, C.F. (2004). The relationship among motivational orientations, climate for organization innovation \& employee innovative behavior: A test of Amabile's motivational synergy model. Journal of Management, 21, 571-592. 
Tushman, M.L. \& Nadler, D.A. (1986). Organizing for innovation. California Management Review, 28(3), 74-92. https://doi.org/10.2307/41165203

Van de Ven, A. (1986). Central problems in the management of innovation. Management Science, 32, 590-607. https://doi.org/10.1287/mnsc.32.5.590

Vandewalle, D. (1997). Development and validation of a work domain goal orientation instrument. Educational and psychological measurement, 57(6), 995-1015. https://doi.org/10.1177/0013164497057006009

Verona, G. (2006). Innovation and virtual environments: toward virtual knowledge brokers. Organizational studies, 27(6), 765-788. https://doi.org/10.1177/0170840606061073

Wahyudi, S., Udin, U., Yuniawan, A. \& Rahardja, E. (2019). Person-Organization Fit, Knowledge Sharing Behaviour \& Innovative Work Behaviour: A Self-determination Perspective. International Journal of Innovation, Creativity \& Change, 4(4), 145-161.

Wang, G. (2011). Transformational leadership and performance across criteria and levels: a meta-analytic review of 25 years of research. Group and organization management, 36(2), 223-270. https://doi.org/10.1177/1059601111401017

Wang, S. \& Noe, R.A. (2010). Knowledge sharing: A review and directions for future research. Human resource management review, 20, 115-131. https://doi.org/10.1016/j.hrmr.2009.10.001

West, M. \& Farr, J. (1990). Innovation at work: Psychological perspectives. Social behavior, 4, 15-30.

Woodman, R.W., Sawyer, J.R. \& Griffin, R.W. (1993). Toward a theory of organizational creativity. Academy of management review, 18, 293-321. https://doi.org/10.5465/amr.1993.3997517

Yu, C., Yu, T.F. \& Yu, C.C. (2013). Knowledge sharing, organizational climate and innovative behavior: a cross-level analysis of effects. Social behavior and personality, 4l(1), 143-156. https://doi.org/10.2224/sbp.2013.41.1.143

Yuan, F \& Woodman, R.W. (2010). Innovative behavior in the workplace: the role of performance and image outcome expectations. Academy of management journal, 53(2), 323-342. https://doi.org/10.5465/amj.2010.49388995

Zhou, J. (2003). Feedback valence, feedback style, task autonomy \& achievement orientation: interactive effects on $\begin{array}{lllll}\text { creative performance. Journal of applied psychology, } & \text { 83, } & \text { 261-276. }\end{array}$ http://dx.doi.org/10.1037/0021-9010.83.2.261

Zhu, C. \& Mu, R. (2016). Followers' innovative behavior in organizations: the role of transformational leadership, psychological capital and knowledge sharing. Frontiers of Business Research in China, 10(4), 636-663. 